e-Journal Al-Syakhsiyyah: Journal of Law \& Family Studies, Vol. 2 No.1 (2020)

(C) Fakultas Syariah IAIN Ponorogo (2020)

Published Online ; Juni 2020

\title{
POLA PEMENUHAN HAK ASUH ANAK PADA KELUARGA BURUH MIGRAN INDONESIA: AN MAQASHID SHARIAH PERSPECTIVE
}

\author{
Lukman Santoso \\ Institut Agama Islam Negeri Ponorogo \\ lukmansantoso4@gmail.com \\ Dawam Abror \\ Institut Agama Islam Negeri Ponorogo \\ dawamabrori1724@gmail.com
}

\begin{abstract}
ABSTRAK : Dalam institusi keluarga, pemenuhan hak-hak anak menjadi bagian urgen yang harus diperhatikan orang tua. Banyak kasus yang muncul di masyarakat bagaimana hak anak terabaikan karena berbagai faktor, semisal karena pekerjaan, kesibukan, kepentingan orang tua, dan bahkan ketika menjadi tenaga kerja di luar negeri. Penelitian ini bertujuan untuk mengeksplorasi tentang bagaimana pola pemenuhan hak asuh anak keluarga tenaga kerja Indonesia di Desa Madusari Ponorogo di tinjau dari perundang-undangan dan maqāsid sharīah. Metode penelitian yang digunakan adalah metode penelitian kualitatif. Adapun teknik pengumpulan data adalah menggunakan teknik interview (wawancara), observasi dan kajian dokumen. Kesimpulan yang diperoleh sebagai temuan hasil penelitian yaitu: Pertama, pelaksanaan pemenuhan hak asuh anak dalam keluarga Tenaga Kerja Indonesia di Desa Madusari Ponorogo sebagian sudah terlaksana dan sebagian belum terlaksana dengan baik. Adanya dampak yang serius terhadap anak yang ditinggal pergi menjadi Tenaga kerja Indonesia. Walaupun kebutuhan anak tercukupi tetapi hal lain seperti masalah pendidikan anak masih belum terpenuhi dengan baik yang berakibat bagi masa depan sang anak yang kurang baik. Kurangnya kasih sayang dari orang tuanya langsung menyebabkan anak kurang diperhatikan. Hal ini sangat berdampak bagi karakter anak yang cenderung mengarah pada prilaku negatif. Kedua, pelaksanaan pemenuhan hak asuh anak dalam keluarga Tenaga Kerja Indonesia di Desa Madusari Ponorogo secara umum masih belum semuanya terpenuhi. Memelihara segala sesuatu yang bersifat pokok (daruriyyah) sesuai dengan tujuan hukum Islam yaitu memelihara agama (hifd ad-din), memelihara jiwa (hifạ an-nafs), memelihara akal (hifd al-'aql), memelihara keturunan (hifd an-nasb), memelihara harta (hifg̣ al-māl) yang kesemua itu merupakan bagian dari maqāșid alsharîah masih ada yang terabaikan. Hal ini sangat berpengaruh bagi kemaslahatan anak. Hal ini dapat membahayakan bagi prilaku anak yang akan menimbulkan kemadharatan bagi masa depan anak.
\end{abstract}

Kata Kunci: Hak Asuh Anak, Tenaga Kerja Indonesia; Maqāṣid sharī‘ah

ABSTRACT : In family institutions, the fulfillment of children's rights becomes an urgent part that must be considered by parents. Many cases have arisen in the 
community of how children's rights have been neglected due to various factors, such as because of work, busyness, the interests of parents, and even when working abroad. This study aims to explore how the pattern of the fulfillment of children's rights of Indonesian migrant workers' families in the Madusari Ponorogo Village in terms of legislation and maquassid sharī'ah. The research method used is a qualitative research method. The data collection technique is to use interview techniques, observation and document review. The conclusions obtained as research findings are: First, the implementation of the fulfillment children's rights in the family of Indonesian Workers in Madusari Ponorogo has partly been implemented and partly not yet well implemented. There is a serious impact on children left behind who become Indonesian workers. Although the needs of children are fulfilled, other things such as children's education problems are still not being met properly which results in the children's future that is not good. Lack of affection from his parents directly causes the children to be overlooked. This is very impacting on the character of children who tend to lead to negative behavior. Second, the implementation of fulfilling children's rights in the families of Indonesian Workers in Madusari Ponorogo Village in general is still not all fulfilled. Maintaining everything basic (daruriyyah) by the objectives of Islamic law, namely maintaining religion (hifd ad-din), preserving the soul (difd annafs), preserving reason (hifd al-'aql), preserving offspring (hifd an-nasb) , preserving the treasures (hif̣̣ al-māl) which are all part of the maqāsid al-sharī'ah are still neglected. This is very influential for the benefit of children. This can endanger the child's behavior which will cause harm to the children's future.

\section{Keywords: Child Custody, Indonesian Workers; Maqāșid sharī'ah}

\section{PENDAHULUAN}

Dalam Islam, secara fundamental perkawinan merupakan ikatan yang sakral. ${ }^{1}$ Dimensi ini juga diadopsi dalam Undang-Undang No. 1 Tahun 1974 Tentang Perkawinan. ${ }^{2}$ Sakralitas perkawinan ini kemudian berimplikasi pada tujuannya, yakni menerapkan pranata keluarga sebagai subjek dalam membiasakan pengalaman-pengalaman ajaran normatif agama. Fungsi keluarga adalah menjadi pelaksana pendidikan yang paling dasar. Sebab keluarga salah satu diantara lembaga pendidikan informal, ibu bapak yang dikenal mula pertama oleh putra putrinya dengan segala perlakuan yang diterima dan dirasakannya, dapat menjadi dasar pertumbuhan pribadi/kepribadian sang anak itu sendiri. ${ }^{3}$

Dari dampak terjadinya perkawinan salah satunya yaitu untuk meneruskan keturunan dengan mempunyai anak. Anak merupakan titipan dari Allah Swt kepada orang tua yang harus dijaga dan diasuh dengan sebaik-baiknya dan mendidik dan memenuhi segala kebutuhannya.

1 Mardani, Hukum Perkawinan Islam di Dunia Islam Modern, (Yogyakarta: Graha Ilmu, 2011) 4. Lihat juga Syaikh Hasan Ayyub, Fikih Keluarga, (Jakarta: Pustaka Alkautsar, 2001) 29.

2 Tihami dan Sohari Sahrani, Fikih Munakahat, (Jakarta: PT Rajagrafindo Persada, 2010) 6.

${ }^{3}$ Ibid, 16. 
Sebagaimana dijelaskan dalam Pasal 45 UU No 1 Tahun 1974 Tentang Perkawinan bahwa (1) Kedua orang tua wajib memelihara dan mendidik anak-anak mereka sebaik-baiknya, (2) Kewajiban orang tua berlaku sampai anak itu kawin atau dapat hidup mandiri, kewajiban akan berlaku terus meskipun perkawinan antara kedua orang tua putus. ${ }^{4}$

Harus muncul dalam kesadaran orang tua bahwa bagaimanapun anak adalah amanah Allah yang dipercayakan kepada orang tua. Dengan demikian, sebagai seorang muslim pantang mengkhianati amanat Allah sebagai orang tua berupa karunia kewajiban mengasuh anak. Di antara sekian perintah Allah berkenaan dengan amanat-Nya yang berupa anak adalah bahwa setiap orang tua wajib mengasuh dan mendidik anak-anaknya dengan baik dan benar. Hal itu dilakukan agar tidak menjadi anak-anak yang lemah iman dan lemah kehidupan duniawinya, namun agar dapat tumbuh dewasa menjadi generasi yang sholeh. ${ }^{5}$

Sementara itu, dalam Pasal 26 ayat (1) UU No. 23 Tahun 2003 Tentang Perlindungan Anak dijelaskan bahwa orang tua memiliki kewajiban dan bertanggung jawab pula untuk: mengasuh, memelihara, mendidik, dan melindungi anak; menumbuhkembangkan anak sesuai dengan kemampuan, bakat, dan minatnya; dan mencegah terjadinya perkawinan pada usia anakanak. ${ }^{6}$ Demikian pula dalam Kompilasi Hukum Islam Pasal 77 ayat (3) dijelaskan bahwa suami istri memikul kewajiban untuk mengasuh dan memelihara anak-anak mereka, baik mengenai pertumbuhan jasmani, rohani maupun kecerdasannya dan pendidikan agamanya. ${ }^{7}$

Menurut Fakhrurrazi dan Noufa Istianah dalam kajiannya menjelaskan bahwa pemeliharaan hak asuh anak menurut hukum Islam yaitu melakukan pemeliharaan anak yang masih kecil, baik laki-laki maupun perempuan, atau yang sudah besar tetapi belum tamyiz, menyediakan sesuatu yang menjadi kebaikannya, menjaganya dari sesuatu yang menyakiti dan merusaknya, mendidik jasmani, rohani, akhlaknya agar mampu berdiri sendiri menghadapi hidup dan memikul tanggung jawab. ${ }^{8}$

Berangkat dari latar belakang tersebut, dan berdasarkan pada beberapa penelitian yang relevan tentang hak asuh anak, misalnya Maswandi, 9 Zainal Fanani, ${ }^{10}$ Uswatun Kasanah, ${ }^{11}$ Nurismi Giarti, ${ }^{12}$ M. Mujib

${ }^{4}$ Pasal 45 ayat 1 dan 2 Undang-Undang No. 1 Tahun 1974 Tentang Perkawinan. Lihat juga Abd. Rahman Ghazaly, Fiqh Munakahat, (Jakarta Timur: Prenada Media, 2003) 176. 5-7.

${ }^{5}$ Mansur, Pendidikan Anak Usia Dini dalam Islam, (Yogyakarta: Mitra Pustaka, 2004)

${ }^{6}$ Pasal 23 ayat 1 Undang-Undang No. 23 Tahun 2003 Tentang Perlindungan Anak.

7 Pasal 77 Ayat 3 Kompilasi Hukum Islam.

8 Fakhrurrazi dan Noufa Istianah," Hak Asuh Anak: Suatu Analisa Terhadap Putusan Mahkamah Syar'iyah Langsa Tentang Pengalihan Hak Asuh Anak ", Jurnal Hukum Islam dan Perundang-undangan, Vol. 4 (2017), 2.

9 Maswandi, "Hak Asuh Anak Yang Belum Dewasa Setelah Perceraian," Jurnal Ilmu Pemerintahan dan Sosial Politik, Vol 1 (2017), 29. 
Bahkiyar Sarifudin A.,13 dan Moh. Qadarusman, ${ }^{14}$ penelitian ini memiliki fokus yang berbeda dari beberapa kajian tersebut. Berangkat dari fakta di desa Madusari bahwa banyak ditemui keluarga yang bekerja menjadi Tenaga Kerja Indonesia (TKI) di luar negeri. Di Desa Madusari Kecamatan Siman Kabupaten Ponorogo ada kurang lebih 30 orang yang menjadi TKI. Mayoritas Tenaga kerja di Desa Madusari Kecataman Siman Kabupaten Ponorogo sudah menikah dan mempunyai anak. Dan ada 12 orang yang sudah mempunyai anak yang masih kecil. Rata-rata anak mereka diasuh oleh nenek, bibi, paman dan saudara lainnya. ${ }^{15}$

Di Desa Madusari Kabupaten Ponorogo banyak ditemui keluarga yang bekerja keluar negeri, khususnya istri. Mereka bekerja keluar negeri karena untuk merubah nasib perekonomian keluarga mereka. Sebagian besar suami mereka bekerja serabutan sehingga tidak cukup untuk memenuhi kebutuhan keluarganya. Sebenarnya istri-istri mereka ingin membantu suaminya dalam memenuhi kebutuhan keluarganya akan tetapi karena sangat sulitnya lapangan pekerjaan bagi ibu rumah tangga dan kurangnya kepercayaan dalam diri mereka akhinya mereka memutuskan untuk bekerja ke luar negeri menjadi TKI. Mereka yang bekerja di luar negeri mempunyai anak-anak yang rata-rata masih sekolah SD, SMP, maupun SMA. ${ }^{16}$

Mereka meninggalkan anak-anak mereka untuk memenuhi kebutuhan ekonomi keluarga. Karena di Madusari khususnya, dan Ponorogo pada umumnya lowongan pekerjaan sangatlah minim dan upah yang didapat tidak cukup untuk memenuhi kebutuhan keluarga. Anak-anak yang mereka tinggalkan ada berbagai macam usia mulai dari baru lahir, sampai usia remaja yang sebenarnya harus mendapatkan perhatian khusus. Sehingga anak-anaknya tersebut dititipkan kepada sudaranya, kakek dan neneknya, ataupun pamannya.

10 Zainal Fanani, "Implementasi Pemberian Nafkah Dan Pemeliharaan Anak Dalam Perspektif Undang-Undang Republik Indonesia Nomor 1 Tahun 1974 Tentang Perkawinan (Studi Kasus Keluarga Tenaga Kerja Indonesia Dan Bercerai Di Desa Prejegan Kecamatan Sukorejo Kabupaten Ponorogo)", Skripsi, (Ponorogo: IAIN Ponorogo, 2014)

${ }_{11}$ Uswatun Kasanah, Peran seorang ibu yang bekerja sebagai TKW terhadap anak di Desa Pengkol Kecamatan Kauman Kabupaten Ponorogo (perspektif ulama NU dan Muhammadiyah Kabupaten Ponorogo), Skripsi, (Ponorogo: IAIN Ponorogo, 2015)

12 Nurismi Giarti, "Pengasuhan Anak di kalangan Kuli Perempuan di desa Ngampel, Skripsi, (Ponorogo: IAIN Ponorogo, 2015)

${ }^{13}$ M. Mujib Bahkiyar Sarifudin A, Tinjauan Hukum Islam Tentang Hak Asuh Anak Terlantar diIndonesia, Skripsi, (Yogyakarta: UIN Sunan Kalijaga, 2017).

${ }^{14}$ Moh. Qadarusman, Pemenuhan Hak-Hak Anak Ditinjau dari Undang-Undang No. 35 Tahun 2014 Tentang Perlindungan Anak dan Hukum Islam (Studi Kasus Keluarga Tenaga Kerja Indonesia Desa Pakong Kec. Pakong Kab. Pamekasan), Skripsi, (Malang: UIN MALIKI, 2018).

${ }^{15}$ Bapak Samsuri, Hasil Wawancara, 17 Juli 2019.

16 Bapak Suwito, Hasil Wawancara, 07 Desember 2018. 
Penelitian ini merupakan penelitian lapangan (field research). Dengan cara mencari data secara langsung dengan melihat obyek yang akan diteliti, ${ }^{17}$ yaitu tentang pemenuhan hak asuh anak dalam keluarga TKI di Desa Madusari. Pendekatan yang peneliti gunakan adalah pendekatan kualitatif. Dengan menggunakan data yang diperoleh dari hasil wawancara, catatan lapangan, dan bahan dokumen lainnya. ${ }^{18}$ Pemilihan desa Madusari sebagai objek dikarenakan sebagian besar warganya merupakan TKI di luar negeri. Adapun pengumpulan data dilakukan dengan observasi, wawancara dan analisis data dokumen. Berpijak pada latar belakang diatas, serta dengan menggunakan metode dan pendekatan tersebut, maka penelitian ini akan memfokuskan kajian pada bagaimana problema pemenuhan hak-hak anak pada keluarga TKI di Desa Madusari Ponorogo terjadi serta bagaimana maqashid syariah melihat problema itu.

\section{Konsep Hak Anak dalam Hukum}

Hak anak menjadi penting dalam dimensi hukum. Sebagaimana dijelaskan dalam Pasal 1 UU No 35 Tahun 2014 tentang perlindungan anak ditegaskan bahwa anak adalah seseorang yang belum berusia 18 tahun, termasuk anak yang masih dalam kandungan. ${ }^{19}$ Sementara menurut UU No. 4 Tahun 1979 tentang kesejahteraan anak, anak difungsikan sebagai potensi serta penerus cita-cita bangsa yang dasar-dasarnya telah diletakkan oleh generasi sebelumnya. Hal ini selaras dengan pengertian anak dalam UU No. 3 Tahun 1997 tentang pengadilan anak dan PP No. 54 Tahun 2007 tentang pengangkatan anak. Ketentuan tersebut menerangkan bahwa anak yang masih dalam kandungan pun dikategorikan anak sampai dengan anak berusia 18 tahun. ${ }^{20}$

Hak anak adalah bagian dari hak asasi manusia yang wajib dijamin, dilindungi, dan dipenuhi oleh orang tua, keluarga, masyarakat, Negara, pemerintah, dan pemerintah daerah. ${ }^{21}$ Pemeliharaan anak juga mengandung arti sebuah tanggung jawab orang tua untuk mengawasi, memberi pelayanan yang semestinya serta mencukupi kebutuhan hidup dari seorang anak oleh orang tua. Selanjutnya, tanggung jawab berupa pemeliharaan berupa pengawasan dan pelayanan serta pencukupan nafkah tersebut bersifat kontinu sampai anak tersebut mencapai batas umur yang legal sebagai orang dewasa yang telah mampu berdiri sendiri.

17 Amiruddin dan Zainal Asikin, Pengantar Metode Penelitian Hukum, (Jakarta: PT Raja Grafindo Persada, 2004), 30.

18 Sutrisno Hadi, Metode Riset (Yogyakarta: Gajahmada, 1980), 3.

19 Pasal 1 ayat 1 Undang-Undang Nomor 35 Tahun 2014 Tentang Perlindungan Anak.

20 Siska Lis Sulistiani, Kedudukan Hukum Anak, (Bandung: PT Refika Aditama, 2015), 15.

21 Pasal 1 ayat 2 Undang-Undang Nomor 35 Tahun 2014 Tentang Perlindungan Anak. 
Islam memberikan pandangan komprehensif terkait pengasuhan anak, hal ini juga menyangkut pemenuhan hak asasi anak. Hak tersebut secara umum meliputi hak anak sebelum dan sesudah dilahirkan, hak dalam kesucian keturunan, hak anak dalam menerima pemberian nama yang baik, hak anak dalam menerima susuan, hak anak dalam mendapat asuhan, perawatan pemeliharaan, hak dalam memiliki harta benda atau hak warisan demi kelangsungan hidup anak yang bersangkutan serta hak anak dalam bidang pendidikan dan pengajaran. ${ }^{22}$

Dalam Islam juga dijelaskan dua landasan utama terkait permasalahan anak. Pertama, kedudukan dan hak-hak anak; dan Kedua, pembinaan sepanjang pertumbuhannya. Dalam konteks kehidupan modern yang ditandai globalisasi dalam semua aspek kehidupan manusia, pemeliharaan anak perlu dipahami secara lebih leluasa dan menyeluruh. Hal ini dimaksudkan agar orang tua tidak hanya memperioritaskan kewajibannya pada terpenuhinya kewajiban materiil si anak, akan tetapi lebih dari itu, yaitu kebutuhan mereka akan cinta dan kasih sayang dari kedua orang tuanya menjadi penentu pembentukan kepribadian si anak. Apabila hal tersebut tidak dipenuhi, maka si anak kemungkinan besar akan mendapat pengaruh negatif dari pergaulan mereka diluar rumah. Hal ini yang merupakan acuan didalam hukum Islam. ${ }^{23}$

Kendati kedua orang tua berkewajiban memelihara anak, namun Islam lebih menekankan kepada ibu. Pertimbangannya adalah rasa kasih sayang dan lemah lembut seorang ibu lebih sesuai dengan keadaan anak dibanding ayah. Dalam sebuah kisah dikemukakan bahwa suatu ketika datang seorang perempuan (membawa seorang anak) menghadap Rasulullah lalu berkata: "Ya Rasulullah, anak ini lahir dari kandunganku, pangkuanku merupakan tempatnya berlindung dan air susuku yang diminumnya. Ayahnya telah menceraikanku lalu bermaksud mengambil anak ini." Rasulullah menjawab: "kamu lebih berhak terhadap anak ini selama kamu belum kawin lagi". ${ }^{24}$

Dalam suatu rumah tangga yang aman dan damai, segala sesuatu yang menyangkut kesejahteraan anak adalah dibawah pengamatan kedua orang tuanya. Suami isteri bahu membahu, bekerja sama memnuhi hidup semua keperluan anaknya, anak pun merasa tentram dalam pertumbuhan jamaniah dan rohaniahnya. Semua orang sangat mengidam-idamkan hal yang demikian, rumah tangganya adalah istana baginya selama hayat

${ }^{22}$ Fuadi Abdullah,"Pemenuhan Hak Anak Asuh oleh Pengelola Panti," Jurnal Ilmu Hukum, 1 (2013), 4.

${ }^{23}$ Mohammad Hifni, "Hak Asuh Anak Pasca Perceraian Suami Istri dalam Perspektif Hukum Islam," Jurnal Hukum Keluarga Islam, 2 (2016), 55. Lihat juga Ahmad Rofiq, Hukum Islam di Indonesia, (Jakarta: PT Rajagrafindo Persada, 1995), 235.

${ }^{24}$ Yaswirman, Hukum Keluarga Karakteristik dan Prospek Doktrin Islam dan Adat dalam Masyarakat Matrelenial Minangkabau, (Jakarta: Rajawali Pers, 2013), 246. Lihat juga Amiur Nuruddin dan Azhari Akmal Tarigan, Hukum Perdata Islam di Indonesia, (Jakarta: Prenada Media, 2004), 293-294 
dikandung badan. ${ }^{25}$ Pendidikan yang lebih penting adalah pendidikan anak dalam pangkuan ibu dan bapaknya, karena dengan adanya pengawasan dan perlakuan akan dapat menumbuhkan jasmani dan akalnya, membersiahkan jiwanya, serta mempersiapkan diri anak dalam menghadapi kehidupannya di masa yang akan datang. ${ }^{26}$

Anak sebagai sebuah pribadi yang sangat unik dan memiliki ciri yang khas. Walaupun ia dapat bertindak berdasarkan perasaan, pikiran dan kehendaknya sendiri, ternyata lingkungan sekitar mempunyai pengaruh yang cukup besar dalam membentuk perilaku seorang anak. Untuk itu bimbingan, pembinaan dan perlindungan dari orang tua, guru, serta orang dewasa lainnya sangat dibutuhkan oleh anak di dalam perkembangannya. ${ }^{27}$

Dalam konteks Indonesia, meskipun UU No 39 Tahun 1999 tentang Hak Asasi Manusia yang telah mencantumkan tentang hak masyarakat, pemerintah dan untuk memberikan perlindungan pada anak, maka masih diperlukan undang-undang mengenai perlindungan anak sebagai landasan yuridis bagi pelaksanaan dan tanggung jawab tersebut.

Selanjutnya dalam UU No 23 Tahun 2002, Bab I Pasal 1 ditegaskan bahwa anak adalah seseorang yang belum berusia 18 tahun, termasuk anak yang masih dalam kandungan. Perlindungan anak adalah segala kegiatan yang menjamin dan melindungi anak dan hak-haknya agar dapat hidup, tumbuh, berkembang, dan berpartisipasi, secara optimal sesuai dengan harkat dan martabat kemanusiaan, serta mendapat perlindungan dari kekerasan dan diskriminasi. Sedangkan hak anak adalah bagian dari hak asasi manusia yang wajib dijamin, dilindungi, dan dipenuhi oleh orang tua, keluarga, masyarakat, pemerintah dan negara. Dengan demikian hak-hak anak meliputi:

a. Tumbuh kembang, dan berpartisipasi secara wajar sesuai dengan harkat dan martabat kemanusiaan. ${ }^{28}$

b. Mendapat nama sebagai identitas diri dan status kewarganegaraan. ${ }^{29}$

c. Diasuh oleh orang tuanya sendiri, kecuali orang tuanya tidak dapat menjamin tumbuh kembang anak, maka berhak diasuh atau diangkat sebagai anak asuh atau anak angkat oleh orang lain sesuai aturan hukum yang sah. ${ }^{30}$

25 Peunoh Daly, Hukum Perkawinan Islam, (Jakarta: PT Bulan Bintang, 2005), 100.

26 Tihami dan Sohari Sahrani, Fikih Munakahat, (Jakarta: PT Rajagrafindo Persada, 2009), 217.

27 M. Nasir Djamil, Anak Bukan Untuk di Hukum, (Jakarta: Sinar Grafika, 2013), 11.

28 Pasal 4 UU No 35 Tahun 2014 tentang Perubahan Atas UU No 23 Tahun 2002 tentang Perlindungan Anak

${ }^{29}$ Pasal 5 UU No 35 Tahun 2014 tentang Perlindungan Anak

30 Pasal 14 UU No 35 Tahun 2014 tentang Perlindungan Anak 
d. Beribadah menurut agamanya, berpikir, dan berekspresi sesuai dengan tingkat kecerdasan dan usianya, dalam bimbingan orang tua/walinya. ${ }^{31}$

e. Memperoleh pelayanan kesehatan dan jaminan sosial sesuai dengan kebutuhan fisik, mental, spiritual, dan sosial. ${ }^{32}$

f. Memperoleh pendidikan dan pengajaran dalam rangka pengembangan pribadinya dan tingkat kecerdasannya sesuai dengan minat dan bakatnya.

g. Menyatakan dan didengar pendapatnya, menerima, mencari, dan memberikan informasi sesuai dengan tingkat kecerdasan dan usianya demi pengembangan dirinya sesuai dengan nilai-nilai kesusilaan dan kepatutan. ${ }^{33}$

h. Penyandang cacat berhak memperoleh rehabilitasi, bantuan sosial dan pemeliharaan taraf kesejahteraan sosial. ${ }^{34}$

i. Mendapat bantuan hukum dan bantuan lainnya bagi anak yang menjadi korban dan pelaku tindak pidana. ${ }^{35}$

Sementara dalam Islam terdapat beberapa petunjuk tentang perlindungan terhadap hak-hak anak. Sejumlah ayat al-Qur'an dan hadits Nabi SAW secara garis besar mengemukakan hak-hak anak sebagai berikut:

a. Hak anak untuk hidup. ${ }^{36}$

b. Hak anak dalam kejelasan nasabnya. ${ }^{37}$

c. Hak anak dalam pemberian nama yang baik. ${ }^{38}$

d. Hak anak dalam memperoleh ASI

e. Hak anak dalam mendapatkan asuhan, perawatan dan pemeliharaan. ${ }^{39}$

f. Hak anak dalam kepemilikan harta benda. ${ }^{40}$

g. Hak anak dalam memperoleh pendidikan dan pengajaran. ${ }^{41}$

Perhatian Islam terhadap hak-hak anak ini mengisyaratkan bahwa anak harus mendapat apresiasi sebagaimana orang dewasa, bahkan anak-

31 Pasal 6 UU No 35 Tahun 2014 tentang Perlindungan Anak

32 Pasal 9 ayat (1) UU No 35 Tahun 2014 tentang Perlindungan Anak

33 Pasal 10 UU No 35 Tahun 2014 tentang Perlindungan Anak

34 Pasal 14 UU No 23 tahun 2002 Tentang Perlindungan Anak.

35 Mufidah, Psikologi Keluarga Islam Berwawasan Gender, (Malang: UIN-MALIKI PRESS, 2013), 271-273.

${ }^{36}$ Departemen Agama, Al-Qur'an dan Terjemahnya, (Semarang: PT Karya Toha, TT), 428-429. Lihat juga Mufidah, Psikologi Keluarga Islam Berwawasan Gender, (Malang: UINMaliki Press, 2013) 274.

${ }^{37}$ Departemen Agama, Al-Qur'an dan Terjemahnya, (Semarang: PT Karya Toha, TT), 667. Lihat juga Mufidah, Psikologi Keluarga Islam Berwawasan Gender, (Malang: UIN-Maliki Press, 2013) 276.

38 Ibid., 277.

${ }^{39}$ Ibid., 278.

${ }^{40}$ Departemen Agama, Al-Qur'an dan Terjemahnya, (Semarang: PT Karya Toha, TT), 53. Lihat juga Mufidah, Psikologi Keluarga Islam Berwawasan Gender, (Malang: UIN-Maliki Press, 2013) 279.

${ }^{41}$ Mufidah, Psikologi Keluarga Islam Berwawasan Gender, 279. 
anak lebih sensitif terhadap masalah-masalah sosial di lingkungannya, sehingga pendidikan, bimbingan, dan perhatian terhadap anak lebih tinggi intensitasnya agar mereka dapat melalui proses tumbuh kembang secara wajar. Namun demikian dalam realitasnya di dalam masyarakat muslim sendiri masih banyak terjadi kasus-kasus penelantaran anak, hal ini tentu penting untuk mendapat perhatian khusus. ${ }^{42}$

\section{Potret Pengasuhan dan Pemeliharaan Anak di Kalangan Keluarga TKI di Desa Madusari}

Desa Madusari merupakan Desa yang terletak di Kecamatan Siman Kabupaten Ponorogo. Sebagian besar penduduk madusari berkerja sebagai Petani, Pedagang, Peternak, PNS dan sebagian juga ada yang bekerja menjadi TKI di luar negeri. Di Desa Madusari Kabupaten Ponorogo terdapat kurang lebih 30 orang yang menjadi TKI. Mayoritas Tenaga kerja di Desa Madusari Kecataman Siman Kabupaten Ponorogo sudah menikah dan mempunyai anak. Dan ada 12 orang yang sudah mempunyai anak yang masih kecil. Ratarata anak mereka diasuh oleh nenek, bibi, paman dan saudara lainnya. ${ }^{43}$

Berkaitan anak dan hak-haknya, diatur dalam Pasal 4 UU No 35 Tahun 2014 Tentang perlindungan anak dijelaskan bahwa setiap anak berhak untuk dapat hidup, tumbuh, berkembang, dan berpartisipasi secara wajar sesuai dengan harkat dan martabat kemanusiaan, serta mendapat perlindungan dari kekerasan dan diskriminasi".

Dalam konteks tersebut, berdasarkan wawancara dengan beberapa informan maka diketahui bahwa hak anak dalam pasal 4 ini sudah terpenuhi semua, mulai dari hak hidup, tumbuh, berkembang, dan berpartisipasi secara wajar sesuai dengan harkat dan martabat kemanusiaan, serta mendapatkan perlindungan dari kekerasan sudah terlaksana dengan baik di keluarga TKI. Semua informan mengatakan bahwa mereka bekerja ke luar negeri tidak serta merta meninggalkan hak-hak yang menjadi tanggung jawab orang tua. Mereka pergi keluar negeri tujuan utamanya yaitu untuk memenuhi kebutuhan keluarga, terutama anak.

Tentang hal ini Pasal 7 ayat (1) dan (2) UU tersebut menjelaskan bahwa:

(1) Setiap anak berhak untuk mengetahui orang tuanya, dibesarkan, dan diasuh oleh orang tuanya sendiri.

(2) Dalam hal karena suatu sebab orang tuanya tidak dapat menjamin tumbuh kembang anak, atau anak dalam keadaan terlantar maka anak tersebut berhak diasuh atau diangkat sebagai anak asuh atau anak angkat oleh orang lain sesuai dengan ketentuan peraturan perundangundangan yang berlaku.

42 Mufidah, Psikologi Keluarga Islam Berwawasan Gender, (Malang, UIN-MALIKI PRESS, 2013) 271.

43 Bapak Hatim, Hasil Wawancara, 17 Juli 2019. 
Dalam konteks ini anak yang ditinggal pergi menjadi TKI di luar negeri pastinya tidak lagi diasuh langsung dan dibesarkan oleh orang tuanya sendiri. Dalam hal mengetahui orang tuanya, anak mengetahui orang tuanya karena ketika mereka lahir tidak langsung ditinggal pergi menjadi TKI oleh orang tuanya. Namun dalam hal diasuh dan dibesarkan oleh orang tuanya sendiri tidak mereka dapatkan.

Pengasuhan secara langsung oleh orang tua menjadi sesuatu yang sangat penting bagi tumbuh kembang anak. Anak yang biasa ditinggal orang tuanya cenderung memiliki sifat kurang percaya diri. Kurangnya perhatian orang tua yang konsisten, stabil dan tulus, seringkali menjadi penyebab kurang terpenuhinya kebutuhan anak akan kasih sayang, rasa aman, dan perhatian. ${ }^{44}$

Kehilangan kasih sayang ibu akan menyebabkan gangguan jasmani dan kejiwaan serta penyimpangan moral pada anak. Oleh sebab itu, banyak orang yang tidak mendapatkan kasih sayang ibu dan kata-kata indah pada masa kecilnya mudah teperdaya, memiliki kepribadian yang lemah, keras kepala, dan pendengki. Pendek kata, suasana keluarga yang diliputi kasih sayang berpengaruh terhadap kepribadian dan kehidupan masa depan anak.

Sifat kasih sayang ibu berbeda dengan kasih sayang ayah. Kasih sayang dan cinta ibu memiliki akar-akar yang kuat dan kukuh, tidak mudah dicabut. Kemarahannya mudah hilang. Lalu, ia menjadi tenang dan seakanakan tidak pernah terjadi apapun sebelumnya. Sementara itu, kasih sayang ayah sangat tenang, seperti angin sepoi-sepoi, tidak mudah tampak. Namun, ia keras dalam memberikan hukuman. ${ }^{45}$

Akan tetapi kembali lagi ke pasal 7 ayat (2) yang mengatakan bahwa pengasuhan berpindah karena sebab tertentu. Sehingga anak tetap mendapatkan pengasuhan dari orang lain tapi tidak dari orang tuanya. Jadi anak yang ditinggal pergi orang tuanya menjadi TKI tidak terlantar, anak tetap dalam pengasuhan yang dipasrahkan orang tuanya untuk mengasuh, seperti nenek, paman atau bibiya, dan lain sebagainya. Namun tetap kasih sayang dan pengasuhan dari orang tuanya langsung tetap lebih penting dan dibutuhkan oleh anak daripada pengasuhan yang diberikan oleh orang lain. Dalam Pasal 9 ayat (1) dan (2) dijelaskan sebagai berikut:

(1) Setiap anak berhak memperoleh pendidikan dan pengajaran dalam rangka pengembangan pribadinya dan tingkat kecerdasannya sesuai dengan minat dan bakatnya.

(2) Selain hak anak sebagaimana dimaksud dalam ayat (1), khusus bagi anak yang menyandang cacat juga berhak memperoleh pendidikan luar biasa, sedangkan bagi anak yang memiliki keunggulan juga berhak mendapatkan pendidikan khusus.

${ }^{44}$ Mufidah, Psikologi Keluarga Islam Berwawasan Gender, (Malang: UIN-Maliki Press, 2013), 289.

${ }^{45}$ Ija Suntana, Etika Pendidikan Anak (Bandung: Pustaka Setia, 2015), 62. 
Pendidikan bagi anak merupakan kebutuhan vital yang harus diberikan dengan cara-cara yang bijak untuk menghantarkannya menuju kedewasaan dengan baik. Kesalahan dalam mendidik anak dimasa kecil akan mengakibatkan rusaknya generasi yang akan datang. Ayah, Ibu atau orang dewasa lainnya yang turut mempengaruhi pembentukan kepribadian anak yang paling besar pengaruhnya terhadap anak. ${ }^{46}$

Pendidikan merupakan salah satu faktor yang sangat penting untuk meningkatkan martabat dan peradaban manusia. Sebagai seorang pemimpin dalam keluarga, seorang kepala keluarga hendaknya memberikan bimbingan dan pendidikan bagi setiap anggota keluarganya, baik itu istri maupun anakanaknya. Bagi seorang istri, pendidikan sangat penting. Dengan bertambahnya pengetahuan dan wawasan maka akan memudahkan perannya sebagai pengelola dalam rumah tangga dan pendidik utama bagi anak-anaknya.

Bagi anak, keluarga merupakan tempat pertama dan utama dalam pendidikannya. Dari keluarga inilah anak mulai belajar berbagai macam hal, terutama nilai-nilai, keyakinan, akhlak, belajar berbicara, mengenal huruf, angka, dan bersosialisasi. Mereka belajar dari kedua orang tuanya. Anakanak melihat, mendengar, dan melakukan apa yang diucapkan atau dikerjakan orang tuanya. Mereka menirukan seperti apa yang dilakukan orang tuanya. Oleh karena itu, tutur kata dan perilaku orang tua hendaknya dapat menjadi teladan bagi anak-anaknya. Kegiatan positif dan baik harus jadi kebiasaan sehari-hari sehingga anak akan terbiasa mengerjakan perbuatan baik. ${ }^{47}$

Mengingat betapa urgennya fungsi keluarga sebagai lembaga pendidikan pertama dan utama maka pendidikan keluarga harus dan merupakan pendidikan pendahuluan atau persiapan bagi pendidikan pada lembaga sekolah dan masyarakat. ${ }^{48}$

Dari hasil wawancara yang dilakukan oleh peneliti, dapat digarisbawahi, bahwa tentang hak anak dalam memperoleh pendidikan dan pengajaran masih ada yang belum terpenuhi walaupun sebagian suda ada yang terpenuhi. Seperti yang dikatakan Bapak Hatim bahwa pendidikan anak-anak TKI agak terbelakang karena kurangnya perhatian dari orang tuanya, akibatnya prestasinya kurang baik. ${ }^{49}$

Dan juga yang dijelaskan oleh Ibu Winatun bahwa anak dari keluarga TKI sudah putus sekolah pada saat SMP. Hal ini terjadi karena kurangnya perhatian orang tua dalam mendidik anak. ${ }^{50}$

${ }^{46}$ Mufidah, Psikologi Keluarga Islam Berwawasan Gender, (Malang: UIN-Maliki Press, 2013), 280.

${ }^{47}$ Helmawati, Pendidikan Keluarga (Bandung: PT Remaja Rosdakarya, 2014), 48.

48 Mukhlison Effendi, Komunikasi Orang Tua dengan Anak (Ponorogo: STAIN Po Press, 2012), 69.

${ }^{49}$ Lihat Transkrip Wawancara

${ }^{50}$ Ibu Winatun, Hasil Wawancara, 23 Maret 2019. 
Sayangnya, dewasa ini peran orang tua yang memiliki tanggung jawab penuh dalam mendidik anak kini perannya dilimpahkan pada para pendidik formal (guru). Hal ini berkaitan dengan tuntutan kehidupan yang mengakibatkan kedua orang tua harus mencari nafkah untuk memenuhi kebutuhan keluarga. Di samping itu, minimnya waktu (bagi orang tua pekerja) dan minimnya ilmu pendidikan dan pengetahuan para orang tua menjadi alasan mengapa orang tua menyerahkan pendidikan anak-anaknya pada para pendidik formal. Padahal, jelas sekali dalam ajaran Islam memerintahkan agar para orang tua khususnya ayah berperilaku sebagai kepala atau pimpinan dalam keluarga dan juga berkewajiban memelihara keluarganya dari api neraka.

Keluarga sebagai lingkungan pendidikan yang pertama sangat berpengaruh dalam membentuk pola kepribadian anak. Di dalam keluarga anak pertama kali berkenalan dengan nilai dan norma. Pendidikan keluarga memberikan pengetahuan dan keterampilan dasar, agama dan kepercayaan, nilai-nilai moral, norma sosial dan pandangan hidup yang diperlukan anak. ${ }^{51}$

Dalam Pasal 10 dijelaskan bahwa: " Setiap anak berhak menyatakan dan didengar pendapatnya, menerima, mencari, dan memberikan informasi sesuai dengan tingkat kecerdasan dan usianya demi pengembangan dirinya sesuai dengan nilai-nilai kesusilaan dan kepatutan “. Maksudnya adalah memberikan kebebasan kepada anak untuk menyatakan pendapatnya dan didengar terhadap segala hal yang ia tahu. Karena kadang orang tua tetap bersikeras pada keinginannya memaksa anak melakukan hal ini dan itu, tetapi anak tidak suka melakukannya.

Karena alasan inilah anak diberi hak memiliki kebebasan untuk di dengar pendapatnya untuk melindungi mereka dari kekerasan mental ataupun paksaan orang tua melakukan sesuatu yang tidak mereka senangi.

Sementara dalam penjelasan Pasal 11 dijelaskan bahwa setiap anak berhak untuk beristirahat dan memanfaatkan waktu luang, bergaul dengan anak sebaya, bermain, berekreasi, dan berkreasi sesuai dengan minat, bakat, dan tingkat kecerdasannya demi pengembangan diri .

Dalam hal ini terkadang orang tua kurang begitu memahami keinginan anak untuk diberikan kebebasan dalam memilih dan menentukan sesuatu sesuai dengan minat dan bakatnya. Anak cenderung lebih diatur dan dikekang ketika mereka akan bermain bersama dengan teman-temannya. Ini akan menjadi tekanan yang begitu berat bagi anak karena mereka tidak memiliki kebebasan untuk bergerak. Yang harusnya orang tua berikan adalah pengawasan terhadap bermain dan perilaku anak.

Dalam hal ini orang yang mengasuh anak keluarga TKI cenderung memberikan kebebasan tanpa adanya batasan-batasan bagi anak. Akibatnya pergaulan anak tidak terkontrol yang menyebabkan anak terkena pergaulan bebas dan cenderung melakukan hal-hal yang negatif.

${ }^{51}$ Helmawati, Pendidikan Keluarga, (Bandung: PT Remaja Rosdakarya, 2014), 50. 
Bermain juga sangat penting bagi tumbuh kembang anak. Dengan bermain anak dapat berinteraksi dengan teman lain. Interaksi tersebut mengajarkan anak cara merespon, memberi dan menerima, menolak atau setuju dengan ide dan perilaku anak yang lain. Hal itu sedikit demi sedikit akan mengurangi rasa egosentris anak dan mengembangkan kemampuan sosialnya. ${ }^{52}$

Selanjutnya, dalam Pasal 14 disebutkan: “Setiap anak berhak untuk diasuh orang tuanya sendiri, kecuali jika ada alasan dan/atau aturan hukum yang sah menunjukkan bahwa pemisahan itu adalah demi kepentingan terbaik bagi anak dan merupakan pertimbangan terakhir ".

Setiap anak berhak untuk diasuh oleh orang tuanya sendiri. Pada dasarnya pemeliharaan anak menjadi tanggung jawab kedua orang tuanya. Pada konteks ini anak yang ditinggal pergi orang tuanya menjadi TKI tidak lagi diasuh secara langsung oleh orang tuanya sendiri. Akan tetapi orang tuanya memasrahkan pengasuhan anaknya seperti kepada neneknya, paman, atau bibi dan lain sebagainya. Memerka ditinggal pergi orang tuanya mereka menjadi TKI adalah untuk memenuhi kebutuhun keluarga, terutama demi kepentingan terbaik bagi anaknya.

\section{Analisis Pemenuhan Hak Asuh Anak Keluarga TKI Perspektif Maqāṣid sharī'ah}

Pada dasarnya Allah menciptakan dan menetapkan hukum bertujuan untuk menciptakan kemaslahatan dan keselamatan hidup manusia. ${ }^{53}$ Baik kemaslahatan tersebut berupa manfaat atau menolak mudharat (kerugian) bagi kehidupan manusia. Hakikat tujuan hukum Ilahi inilah yang harus senantiasa dijadikan pegangan dan pedoman oleh para mujtahid dalam berijtihad merumuskan hukum-hukum yang tersembunyi itu. Secara umum dapat dirumuskan bahwa tujuan hukum Islam adalah kebahagiaan hidup manusia di dunia dan di akhirat, dengan jalan mengambil yang bermanfaat dan mencegah atau menolak yang merusak. Dengan kata lain, tujuan hukum Islam adalah kemaslahatan hidup manusia, baik rohani maupun jasmani, individual dan sosial. ${ }^{54}$

Dalam Islam terdapat beberapa petunjuk tentang perlindungan terhadap hak-hak anak. Sejumlah ayat al-Qur'an dan hadits Nabi SAW secara garis besar mengemukakan hak-hak anak sebagai berikut:

1. Hak anak untuk hidup

2. Hak anak dalam kejelasan nasabnya

3. Hak anak dalam pemberian nama yang baik

4. Hak anak dalam memperoleh ASI

52 Slamet Suryanto, Dasar-Dasar Pendidikan Anak Usia Dini (Yogyakarta: HIKAYAT Publising, 2005), 121.

53 Hammady al-Ubaidy, al-Syatibi, Maqashid Al-shariah, (Tripoli: al-Jumhariyyah asl-Utma, 1992), 25.

${ }^{54}$ Asmawi, Studi Hukum Islam, (Yogyakarta: Teras, 2012), 107. 
5. Hak anak dalam mendapatkan asuhan, perawatan dan pemeliharaan

6. Hak anak dalam kepemilikan harta benda

7. Hak anak dalam memperoleh pendidikan dan pengajaran ${ }^{55}$

Al-Ghazali mengatakan bahwa maqashid syari'ah dibagi menjadi dua wilayah, yaitu maslahah dunia dan akhirat. Masing-masing wilayah ditegakkan dengan dua langkah, yaitu langkah tahshil (mengusahakan terpenuhinya manfaat) dan ibqa' (usaha menghilangkan mudarat. Kedua wilaya tersebut dilebur lalu dibagi ke dalam lima sektor mașlahah (kulliyat alkhams), yaitu nafs (perlindungan terhadap nyawa), 'aql (perlindungan terhadap akal), din (perlindungan terhadap agama), nasl (perlindungan terhadap keturunan), dan māl (perlindungan terhadap hak milik). Masingmasing didukung oleh aturan hukum Islam (Fikih) dalam seluruh bab sebagaimana yang tercantum dalam kitab-kitab fikih. Aturan ini tahsiniyah. ${ }^{56}$

Melestarikan kelima (atau keenam) hal tersebut adalah keharusan, yang tidak bisa tidak ada, jika kehidupan manusia dikehendaki untuk berlangsung dan berkembang. Kehidupan manusia akan menghadapi bahaya jika akal mereka terganggu, oleh karena itu Islam melarang keras khamar, narkoba dan sejenisnya. Kehidupan manusia akan berada dalam keadaan bahaya jika nyawa mereka tidak dijaga dan dilestarikan dengan berbagai tindakan pencegahan penyakit dan atau jika tidak tersedia sistem penjaminan lingkungan dari polusi, maka dalam rangka inilah kita dapat memahami pelarangan nabi SAW akan penyiksaan terhadap manusia, hewan maupun tumbuhan.

Keberlangsungan hidup manusia juga akan terancam, apabila terjadi krisis ekonomi yang menyeluruh. Oleh karenanya, Islam melarang sebabmusabab terjadinya krisis tersebut seperti monopoli, riba, korupsi dan kecurangan. Keluarga TKI di Desa Madusari Kecamatan Siman Kabupaten Ponorogo pergi Menjadi TKI tidak lain yaitu untuk memenuhi kebutuhan ekomoni keluarga demi kelangsungan hidupnya agar tidak terancam. Dan juga untuk memenuhi hak-hak anak dalam memberikan nafkah.

Demikian pula dengan pelestarian keturunan, yang didudukkan pada martabat yang tinggi oleh Islam, di mana terdapat hukum-hukum untuk mendidik dan memelihara anak-anak serta menjaga keutuhan keluarga (seperti pelarangan zina, durhaka terhadap orang tua, menelantarkan anak atau tidak berlaku adil kepadanya). ${ }^{57} \mathrm{Hal}$ ini bertujuan untuk kesejahteraan dan kemaslahatan anak demi masa depan anak yang baik.

55 Mufidah, Psikologi Keluarga Islam Berwawasan Gender, (Malang, UIN-MALIKI PRESS, 2013) 274-281. 112.

${ }^{56}$ Miftahul Huda, Filsafat Hukum Islam, (Ponorogo: STAIN Ponorogo Press, 2006),

57 Jaser 'Audah, Al-Maqasid Untuk Pemula, terj. Ali Abdelmon'im (Yogyakarta: SUKA-Press, 2013), 8-9. 
Upaya mewujudkan kehidupan dalam Islam adalah Pernikahan. Dengan menikah akan terjalin kekeluargaan. Hubungan suci ini akan menciptakan mawaddah dan rahmah. Kehadiran buah hati dari hubungan suci ini akan menambah rasa kasih sayang suami istri. Segala upaya akan dikerahkan suami untuk menghidupi dan membahagiakan keluarganya. Masa depan sang anak jelas akan mendapat perhatian lebih dari kedua orang tuanya. Mulai dari urusan pendidikan maupun kelangsungan hidupnya. Maha Allah yang telah menjadikan pernikahan sebagian dari tanda-tanda kekuasaan-Nya. ${ }^{58}$

Demikian pula dengan menjaga akal merupakan unsur yang sangat penting bagi kehidupan manusia karena akal itulah yang membedakan hakekat manusia dari makhluk Allah lainnya. ${ }^{59}$ Akal juga sebagai sumber hikmah (pengetahuan), sinar hidayah, cahaya mata hati, dan media kebahagiaan manusia di dunia dan akhirat. Dengan akal, surat perintah dar Allah SWT disampaikan, dengannya pula manusia berhak menjadi pemimpin di muka bumi, dan dengannya manusia menjadi sempurna, mulia, dan berbeda dengan makhluk lainnya. ${ }^{60}$ Jika dilihat dari sisi Jalbu manfa'āh (baik), salah satunya adalah menuntut ilmu atau belajar. ${ }^{61}$ Anak-anak dari keluarga TKI di Desa Madusari mendidik anak mereka dengan disekolahkan yaitu untuk memenuhi hak anak dan juga untuk menjaga kelestarian akal. Tetapi juga ada yang masih belum terpenuhi dalam hal pendidikan anak. Masih ada anak dari keluarga TKI yang putus sekolah. Hal ini menyebabkan akal mereka terancam.

Demikian pula dengan menjaga harta. Harta merupakan suatu yang sangat dibutuhkan manusia karena tanpa harta manusia tidak mungkin bertahan hidup. Oleh karena itu, dalam rangka jalbu manfaat yakni Allah menyuruh untuk mewujudkan dan memelihara harta tersebut dengan cara berusaha. ${ }^{62}$ Keluarga TKI pergi menjadi TKI untuk mencari harta tidak lain untuk memenuhi kebutuhan keluarga terutama bagi anak untuk bertahan hidup.

Dalam hal menjaga agama, Islam menjaga hak dan kebebasan, dan kebebasan yang pertama adalah kebebasan berkeyakinan dan beribadah. Setiap pemeluk agama berhak atas agama dan madzhabnya, ia tidak boleh dipaksa untuk meninggalkannya menuju agama atau madzhab lain, juga tidak boleh ditekan untuk berpindah dari keyakinannya untuk masuk Islam. ${ }^{63}$ Dalam konteks ini semua keluarga TKI di Desa Madusari Kecamatan Siman Kabupaten Ponorogo beragama Islam. Dalam hal memelihara agama

58 M. Subhan DKK, Tafsir Maqashidi, (Kediri: LIRBOYO Press, 2013), 107.

59 Amir Syarifuddin, Ushul Figh 2, (Jakarta:Kencana Prenadamedia Group, 2008), 236.

${ }^{60}$ Ahmad Al-Mursi Husain Jauhar, Maqashid Syariah, (Jakarata: Amzah, 2009), 51.

${ }^{61}$ Amir Syarifuddin, Ushul Figh 2, (Jakarta:Kencana Prenadamedia Group, 2008), 236.

62 Ibid., 238.

${ }^{63}$ Ahmad Al-Mursi Husain Jauhar, Maqashid Syariah (Jakarta: Amzah, TT) 1. 
si anak para orang tua harus menanamkan nilai akidah dan akhlak sesuai ajaran Islam kepada anak. Hal ini bertujuan untuk memelihara agama bagi anak dan demi kemaslahatan anak. Salah satu yang dilakukan keluarga TKI yaitu dengan menyekolahkan anak mereka di lembaga pendidikan Islam.

\section{PENUTUP}

Berdasarkan analisis dalam sub bab sebelumnya, dapat ditarik kesimpulan, Pertama, Implementasi pemenuhan hak asuh anak dalam keluarga TKI di Desa Madusari Kecamatan Siman Kabupaten Ponorogo sebagian sudah terlaksana dan sebagian belum terlaksana dengan baik. Adanya dampak yang serius terhadap anak yang ditinggal pergi menjadi TKI. Walaupun kebutuhan anak tercukupi tetapi hal lain seperti masalah pendidikan anak masih ada yang belum terpenuhi yang berakibat bagi masa depan sang anak yang kurang baik. Kurangnya kasih sayang dari orang tuanya langsung menyebabkan anak kurang diperhatikan. Hal ini sangat berdampak bagi karakter anak cenderung ke arah yang negatif.

Kedua, Implementasi pemenuhan hak asuh anak dalam keluarga TKI di Desa Madusari Kecamatan Siman Kabupaten Ponorogo secara umum masih belum semuanya terpenuhi. Memelihara segala sesuatu yang bersifat daruriyyah sesuai dengan tujuan hukum Islam yaitu hifd ad-din (memelihara agama), hif̣̣ an-nafs (memelihara jiwa), hifḍ al-aql (memelihara akal), hif̣̣ annasb (memelihara keturunan), hifḍ al-māl (memelihara harta) yang kesemua itu merupakan bagian dari maqāṣid al-sharī'ah masih ada yang terabaikan. Hal ini sangat berpengaruh bagi kemaslahatan anak. Hal ini dapat membahayakan bagi anak yang akan menimbulkan kemadharatan bagi masa depan anak.

Maka, berdasarkan kesimpulan tersebut, peneliti memberikan rekomendasi kepada para orang tua yang bekerja ke luar negeri, hendaknya sangat memperhatikan aspek kasih sayang dan perhatian terhadap anak yang ditinggalkan. Orang tua ataupun orang yang dipercaya mengasuh harus tahu dan memahami bahwa pengasuhan anak adalah demi kepentingan dan masa depan anak tersebut dimasa depan. Seharusnya orang tua tidak hanya memenuhi kebutuhan nafkah anak saja, tetapi juga harus memperhatikan hak-hak anak yang lain juga agar hak-hak anak tidak ada yang terabaikan. Jika hak-hak anak masih ada yang terabaikan hal ini akan berpengaruh bagi masa depan anak. 


\section{DAFTAR PUSTAKA}

Abdullah, Fuadi, "Pemenuhan Hak Anak Asuh oleh Pengelola Panti," Jurnal Ilmu Hukum, 1 (2013), 4.

Amiruddin dan Zainal Asikin, Pengantar Metode Penelitian Hukum, Jakarta: PT Raja Grafindo Persada, 2004.

Asmawi, Studi Hukum Islam, Yogyakarta: Teras, 2012.

'Audah, Jasser, Al-Maqasid Untuk Pemula, terj. Ali Abdel mon'im Yogyakarta: SUKA-Press, 2013), 8-9.

Ayyub, Syaikh Hasan, Fikih Keluarga, Jakarta: Pustaka Al-kautsar, 2001.

Daly, Peunoh, Hukum Perkawinan Islam, Jakarta: PT Bulan Bintang, 2005.

Djamil, M. Nasir, Anak Bukan Untuk di Hukum, Jakarta: Sinar Grafika, 2013.

Departemen Agama, Al-Qur'an dan Terjemahnya, Semarang: PT Karya Toha, tt.

Effendi, Mukhlison, Komunikasi Orang Tua dengan Anak, Ponorogo: STAIN Po Press, 2012.

Fakhrurrazi dan Noufa Istianah, "Hak Asuh Anak: Suatu Analisa Terhadap Putusan Mahkamah Syar'iyah Langsa Tentang Pengalihan Hak Asuh Anak“, Jurnal Hukum Islam dan Perundang-undangan, Vol. 4 (2017), 2.

Fanani, Zainal, "Implementasi Pemberian Nafkah Dan Pemeliharaan Anak Dalam Perspektif Undang-Undang Republik Indonesia Nomor 1 Tahun 1974 Tentang Perkawinan (Studi Kasus Keluarga Tenaga Kerja Indonesia Dan Bercerai Di Desa Prejegan Kecamatan Sukorejo Kabupaten Ponorogo)", Skripsi, Ponorogo: IAIN Ponorogo, 2014.

Ghazaly, Abd. Rahman, Figh Munakahat, Jakarta: Prenada Media, 2003.

Giarti, Nurismi, "Pengasuhan Anak di kalangan Kuli Perempuan di desa Ngampel," Skripsi, Ponorogo: IAIN Ponorogo, 2015.

Hadi, Sutrisno, Metode Riset, Yogyakarta: Gajahmada, 1980.

Helmawati, Pendidikan Keluarga, Bandung: PT Remaja Rosdakarya, 2014.

Hifni, Mohammad, "Hak Asuh Anak Pasca Perceraian Suami Istri dalam Perspektif Hukum Islam," Jurnal Hukum Keluarga Islam, 2 (2016), 55.

Huda, Miftahul, Filsafat Hukum Islam, Ponorogo: STAIN Ponorogo Press, 2006.

Jauhar, Ahmad Al-Mursi Husain, Maqashid syariah, Jakarta: Amzah, 2009.

Kasanah, Uswatun, "Peran seorang ibu yang bekerja sebagai TKW terhadap anak di Desa Pengkol Kecamatan Kauman Kabupaten Ponorogo (perspektif ulama NU dan Muhammadiyah Kabupaten Ponorogo)," Skripsi, Ponorogo: IAIN Ponorogo, 2015.

Mansur, Pendidikan Anak Usia Dini dalam Islam, Yogyakarta: Mitra Pustaka, 2004.

Mardani, Hukum Perkawinan Islam di Dunia Islam Modern, Yogyakarta: Graha Ilmu, 2011.

Maswandi, “Hak Asuh Anak Yang Belum Dewasa Setelah Perceraian,” Jurnal Ilmu Pemerintahan dan Sosial Politik, Vol 1 (2017), 29. 
Mufidah, Psikologi Keluarga Islam Berwawasan Gender, Malang: UIN-Maliki Press, 2013.

Nuruddin, Amiur dan Azhari Akmal Tarigan, Hukum Perdata Islam di Indonesia, Jakarta: Prenada Media, 2004.

Qadarusman, Moh., "Pemenuhan Hak-Hak Anak Ditinjau dari UndangUndang No. 35 Tahun 2014 Tentang Perlindungan Anak dan Hukum Islam (Studi Kasus Keluarga Tenaga Kerja Indonesia Desa Pakong Kec. Pakong Kab. Pamekasan)," Skripsi, Malang: UIN MALIKI, 2018.

Rofiq, Ahmad, Hukum Islam di Indonesia, Jakarta: PT Rajagrafindo Persada, 1995.

Sarifudin A, M. Mujib Bahkiyar, “Tinjauan Hukum Islam Tentang Hak Asuh Anak Terlantar di Indonesia," Skripsi, Yogyakarta: UIN Sunan Kalijaga, 2017.

Subhan, M., dkk, Tafsir Maqashidi, Kediri: LIRBOYO Press, 2013.

Sulistiani, Siska Lis, Kedudukan Hukum Anak, Bandung: PT Refika Aditama, 2015.

Suntana, Ija, Etika Pendidikan Anak Bandung: Pustaka Setia, 2015.

Suryanto, Slamet, Dasar-Dasar Pendidikan Anak Usia Dini, Yogyakarta: HIKAYAT Publising, 2005.

Syarifuddin, Amir, Ushul Figh 2, Jakarta: Kencana Prenadamedia Group, 2008.

Tihami dan Sohari Sahrani, Fikih Munakahat, Jakarta: PT Rajagrafindo Persada, 2010.

Ubaidy, Hammady, al-Shatibi wa Maqasid al-Shari'ah, Beirut : Dar Qutaibah, 1992.

Yaswirman, Hukum Keluarga Karakteristik dan Prospek Doktrin Islam dan Adat dalam Masyarakat Matrelenial Minangkabau, Jakarta: Rajawali Pers, 2013.

Undang-Undang No. 1 Tahun 1974 Tentang Perkawinan.

Undang-Undang No. 23 Tahun 2002 Tentang Perlindungan Anak.

Instruksi Presiden No.1 Tahun 1991 Tentang Kompilasi Hukum Islam.

Bapak Samsuri, Hasil Wawancara, 17 Juli 2019.

Bapak Suwito, Hasil Wawancara, 07 Desember 2018

Bapak Hatim, Hasil Wawancara, 17 Juli 2019.

Ibu Winatun, Hasil Wawancara, 23 Maret 2019. 